\title{
A restrictive dose of crystalloids in patients during laparoscopic cholecystectomy is safe and cost-effective: prospective, two-arm parallel, randomized controlled trial [Corrigendum]
}

\author{
Belavić M, Sotošek Tokmadžić V, Brozović Krijan A, et al. \\ Ther Clin Risk Manag. 2018;14:741-751. \\ In this article, the author Josip Žunić did not meet the criteria \\ for authorship and was erroneously included in the authors \\ list. The authors wish to apologize for this error.
}

Therapeutics and Clinical Risk Management is an international, peerreviewed journal of clinical therapeutics and risk management, focusing on concise rapid reporting of clinical studies in all therapeutic areas, outcomes, safety, and programs for the effective, safe, and sustained use of medicines. This journal is indexed on PubMed Central, CAS,
EMBase, Scopus and the Elsevier Bibliographic databases. The manuscript management system is completely online and includes a very quick and fair peer-review system, which is all easy to use. Visit http://www.dovepress.com/testimonials.php to read real quotes from published authors. 